\title{
Strategic Human Resource Management and Organizational Performance in the Nigerian Manufacturing Sector: An Empirical Investigation
}

\author{
Oladipo Jimoh A. (Ph.D) \\ Department of Business Administration \\ University of Ilorin, Nigeria \\ Tel: 234-803-378-1008Ｅ-mail: oladipoui@yahoo.com
}

Abdulkadir Danlami S.

Department of Business Administration

Ibrahim Badamasi Babangida University, Lapai, Nigeria

Tel: 234-805-512-3596 E-mail: abdulkadirdanlami@yahoo.com

Received: December 17, 2010 Accepted: April 11, 2011 doi:10.5539/ijbm.v6n9p46

\begin{abstract}
Despite the relatively large bulk of literature on strategic HRM, there is still an ongoing debate as to whether it exists in reality or is merely rhetoric. This paper attempted to broaden the scope of existing literature by examining the extent to which Strategic HRM is practiced in the Nigerian manufacturing sector as well as its impact on organizational performance. A multi-respondent survey of 21 Nigerian manufacturing companies was undertaken and data collected was subjected to correlation and regression analysis as well descriptive statistics in pursuance of the stated objective of finding a fit between organizational performance and strategic human resource management practices. Results show that strategic HRM was moderately practiced by the companies operating in the Nigerian manufacturing sector. Results also indicate that line management devolvement, innovative recruitment and selection system, regular training and development of personnel, equity based compensation system, performance appraisal system, effective career planning system and a robust employee participation in the organizations' decisions and actions are the key strategic HR practices that influence organizational performance in the Nigerian manufacturing sector. It therefore, implies that companies operating in the Nigerian manufacturing sector should pay more attention to these practices with a view to improving their implementation across the industry.
\end{abstract}

Keywords: Strategic HRM, Devolvement, Integration, Performance, Nigeria, Manufacturing sector

\section{Introduction}

A message frequently found in corporate mission statements and annual reports is that people are a firm's most valuable resource. Having the right personnel at the right place and at the right time is of utmost importance to the survival and success of any organization. The recognition of Human Resource Management (HRM) as a key source of competitive advantage provides professionals working in the human resources (HR) functional areas with elevated organizational status. The acknowledgement of human resource management, however, presents professionals working in the area with a number of role changes and new challenges. For example, the creation of more central strategic roles for the HR function brings with it the expectation that it is not enough for HR to simply partner top management; it has to drive business success.

Several critiques have been raised regarding the value creation of human resource management (HRM) i.e. whether it can contribute directly to the implementation of the strategic objectives of firms and improve performance (e.g. Hope-Hailey et al. 1997). Strategic HRM (SHRM) emerged in the early 1990s laying more emphasis on an integrative and value-driven approach to HRM. SHRM focuses on issues such as the fit between human resource practices and organizational strategic management, the involvement of the HR function in senior management teams, the devolvement of HR practices to line managers and the value that is added to organizational performance by HRM (Bowen and Ostroff, 2004).

Despite research efforts into SHRM (e.g. Becker and Gerhart, 1996; Wright et al. 2003), there exist an ongoing debate as to whether organizations actually practice SHRM, whether line managers are actively involved in transforming HR function to be more strategic and whether SHRM adds value to the bottom line (Martell and 
Carroll, 1995).

Evidence from the advanced economies has affirmatively answered a great deal of these questions. For instance, businesses in America are known to employ SHRM more frequently and passionately than Japanese or Taiwanese businesses (Huang, 1995). Although, a small body of knowledge also exists alluding to SHRM practices in African countries, its tenacity and performance-oriented outcomes are yet to be properly documented. The present study is therefore, an attempt to fill part of this gap using the Nigerian manufacturing sector as a guinea pig. The primary objective of the research work is to examine the effect of SHRM on corporate performance manifesting in growth in sales revenue, financial strength in terms of liquidity and reserves, return on equity, return on assets and profitability. Specifically, the study also examines the extent to which SHRM is practiced in the sector, determines the degree of relationships among the different identified SHRM practices and finally assesses the level of relationships between different SHRM practices and corporate performance of manufacturing companies in Nigeria.

\section{Review of the Literature}

By nature, Strategic Human Resource Management implies a managerial orientation that ensures that human resources are employed in a manner conducive to the attainment of organizational goals and mission. The concept of Strategic Human Resource Management (SHRM) evolved in the 1990s with an increased emphasis on a proactive, integrative and value-driven approach to human resource management (Schuller, 1992). Strategic HRM focuses on several issues including the fit between human resource management practices and organizational strategic goals, the integration of human resource management in the organizational strategic management, the involvement of human resource function in senior management teams, the devolvement of human resource practices to line managers and taking of strategic approach to employee selection, compensation, performance appraisal and the value that is added to the organizational performance by HRM. It has also been defined as the pattern of planned human resource deployments and activities intended to enable an organization to achieve its goals (Wright and McMahan, 1999). The latter definition highlights the two important dimensions that distinguish SHRM from traditional HRM. It links HR practices with the strategic management process of the firm vertically and horizontally, it emphasizes that HR practices are integrated and support each other.

\subsection{Strategic HRM Practices}

\subsubsection{Integration of HRM with Corporate Strategies}

Integration of HRM refers to the involvement of HRM in the formulation and implementation of organizational strategies and the alignment of HRM with the strategic needs of an organization (Schuler and Jackson, 1999). Buyens and De Vos (1999) argue that in order for HR to be a strategic partner, HR managers should be involved in strategic decision making alongside other senior managers, providing greater opportunity to align HR goals, strategies, philosophies and practices with corporate objectives and the implementation of business strategy. This involvement would include the membership of HR managers in the most senior management teams in the organization. This would provide an opportunity for HRM to represent its concerns and influence business strategy from the outset of decision making. The chances of integration and value creation may be further increased if the senior HR manager and the CEO have an opportunity to establish a relationship. In this role, HR managers need to have knowledge of core markets, competitors, costs, profit indicators and stakeholders to be considered equal business partners (Chaddie, 2001). The involvement of a senior HR manager in a firm's senior management team provides an important channel for interactive information flow and communication.

To achieve strategic integration and alignment of HRM with business strategies, a documented HRM strategy would also be useful (Budhwar, 2000; Teo, 2002) as it can make more concrete the role and authority of HR managers in corporate decision making and increase capacity to cope with externalities such as a tight labour market (Cunningham and Deborah, 1995). A documented HRM strategy helps the organization to develop an HRM vision and objectives and to monitor performance. Some empirical evidence from previous research indicates that the full impact of HR practices on organizational performance occurs when HR practices are strategically congruent and consistent with each other (Khatri, 1999).

\subsubsection{Delegation of HR practices to Line Managers}

To make HR managers more available for participation in strategic decision-making process, Budhwar and Khatri (2001) argued that the responsibility of routine execution and administration of HR practices should be delegated to line managers as they have direct and frequent contact with employees.

However, for the benefit of devolvement to be realized, line managers will need to possess appropriate skills to execute HR practices competently and effectively to a benchmarked standard advocated by HR managers (Hall and Torrington, 1998). This means that the senior HR manager needs to be a strategic partner with line managers, providing training, resources, incentive and a communication channel to ensure these HR practices are carried out in accordance with HRM policy (Teo, 2002).

\subsubsection{Selection System}

A rigorous, valid and sophisticated selection system helps in identifying a right candidate with potential to perform. 
A rigorous selection system generates a sense of elitism, creates high expectations of performance, and signals a message of importance of the people to the organization (Pfeffer, 1994). The mismatch between the person and the job can hamper performance levels, whereas a sophisticated selection system can ensure a better fit between the person's abilities and the organization's requirement. Also, selection has been found to be positively related to firm performance (Terpsra and Rozell, 1993).

\subsubsection{Training and Development System}

Organizations can develop and enhance the quality of the current employees by providing comprehensive training and development. Indeed, research indicates that investments in training employees in problem-solving, teamwork and interpersonal relations result in beneficial firm level outcomes (Barak et al., 1999).

\subsubsection{Performance Appraisal System}

Organizations can monitor the development of desired employee attitudes and behaviours through the use of the appraisal mechanisms. This appraisal-based information could be used for changing the selection and training practices to select and develop employees with the desired behaviours and attitudes. However, the effectiveness of skilled employees will be limited unless they are motivated to perform their jobs.

\subsubsection{Compensation System}

Firms can affect the motivation of employees in several ways. They can use performance-based compensation to provide rewards to employees for achieving the specific goals and objectives of the firm. A substantial body of work has provided evidence that incentive-based compensation has an impact on firm performance (Milkovich and Boudreau, 1998).

\subsubsection{Career Planning System}

A well-functioning career planning system may also encourage employees to take more responsibility for their own development, including the development of the skills viewed as critical in the company. A well-planned career development system along with internal advancement opportunities based on merit, results in high motivation among employees, which has an impact on firm performance Milkovich and Boudreau (1998).

\subsubsection{Employee Participation}

The concept of treating employees as the most important asset of an organization is an underlying assumption of HRM. As such, facilitating and enhancing greater employee influence and participation is obviously basic to successful HR practice in organizations. Studies have shown that employee participation is positively related to performance, satisfaction, and productivity of an employee (Verma, 1995).

\section{Studies on Strategic HRM}

The era of strategic HRM was ushered in nearly two decades ago and since then, a behavioral perspective has emerged as the predominant paradigm for research. However, it was only in the 1990s that the concept of bundling of human resource practices became popular and attracted numerous studies. Ferris et al. (1990) made one of the first major attempts to examine how effective management of human resources might contribute to positive organizational performance. In their study of 2,236 firms from the U.S. construction industry, the Ferris group addressed the roles played by three important organizational functions and activities on firm performance: the status and importance of the HRM function, the role of unions and strategic planning. They found that firms that had HRM departments were generally high performers (i.e., larger total sales volume), firms that had a higher percentage of their workforce unionized also performed better than firms with a lower percentage and, finally, firms performed better when they engaged in more formalized strategic planning.

In a comparative study of strategic HRM practices among American-owned, Taiwan-owned and Japanese-owned firms, Huang (1998) examines the strategic level of HRM at 315 Taiwanese business firms. Using the General Linear Model (GLM) and Scheffe multi-range test as methods of statistical analysis, the findings indicate that American-owned businesses were discovered to engage in strategic human resource management (SHRM) more frequently than Japanese- or Taiwan-owned enterprises. A positive relationship was also found between the amount of capital resources available to firms and the extent to which they practiced SHRM. Huang also reported that firms engaging in SHRM received a higher rating than other firms on the indices of organizational morale, financial performance, and overall performance.

Also, based on the questionnaire responses by heads of human resource departments in 191 companies in Singapore, David et al. (2002) examined the relationship between strategic HRM and organizational financial and human resource performance in Singapore. Using descriptive statistics and regression to analyze the data, the results indicate that with the exception of team-based work and performance-based pay, all the other strategic HRM components have a positive impact on the financial performance of a firm. Results also show that all the strategic HRM variables have a positive impact on HR performance.

Singh (2004) investigated the relationship between six HRM practices and firm level performance in India. 359 firms were drawn from firms listed in the Centre for Monitoring Indian Economy (CMIE) database. Of these 359 firms, 82 responded positively to the survey. Using regression and correlation analysis, the study found a 
significant relationship between the two HR practices, namely, training and compensation, and perceived organizational and market performance of firms.

Green et al., (2006) reported that organizations that vertically aligned and horizontally integrated HR function and practices performed better and produced more committed and satisfied HR function employees who exhibited improved individual and organizational performance. Tessember and Soeters (2006) examined how, when and to what extent HR practices affect performance in Eritrea, Africa's youngest and poorest country. They reported that successful implementation of HR practices could enhance individual and civil service organization of Eritrea, but the economic and political environment within which HR practices operate are not conducive. Their study tried to shed some light on the HRM-performance debate within the context of a developing country.

Using a stratified random sampling by industry, Kai et al. (2007) surveyed 231 firms listed on the Australian Stock Exchange (ASE). Using descriptive statistics and correlation analysis, results indicate that strategic integration and devolvement of HRM were practiced to a moderate extent in the firms sampled, and that the degree of alignment of HRM with business objectives and strategies had a positive relationship with perceived firm financial performance.

Som (2008) sampled 69 Indian companies with a view to examining the impact of innovative SHRM practices on firm performance. Using descriptive statistics and regression analysis, results indicate innovative recruitment and compensation practices have a positive significant relationship with firm performance. Their results also show that recruitment, role of the HR department and compensation practices seem to be significantly changing within the Indian firms in the context of Indian economic liberalization. The synergy between innovative HRM practices was not found to be significant in enhancing performance during the liberalization process.

Dimba and K'Óbonyo (2009) investigated the nature of the effect of SHRM practices on organizational performance. The study sought to determine whether the effect of human resource management practices on organizational performance is direct or indirect through employee motivation, and whether employee cultural orientations moderate the relationship between strategic human resource practices and employee motivation. 50 multinational manufacturing companies in Kenya were sampled. One HR manager, 2 line managers and 3 employees from each organization were chosen for the survey. The study adopted the measures developed by Hofstede and Huslid. Using regression analysis, the results indicate that all the variables of SHRM practices, except recruitment and selection were positive and significantly correlated with performance; relationship between SHRM practices and firm motivation did not depend on employee cultural orientations when cultural values were considered; motivation mediated the relationship between SHRM practices and firm performance and motivation affected firm performance.

Okpara and Pamela (2008) examined the extent to which organizations in Nigeria use various HRM practice and the perceived challenges and prospects of these practices. Data were collected from 253 managers in 12 selected companies in 10 cities. Their findings reveal that HRM practices, such as training, recruitment, compensation, performance appraisal and reward systems are still in place and that issues of tribalism, AIDS, training and development and corruption are some of the challenges facing HRM in Nigeria.

\section{Research Hypotheses}

In order to achieve the objectives designed for this study, the following research hypotheses are stated in their null form based on the revelations in the review of literature concerning SHRM practices and firms' performance.

\section{Hypothesis One:}

Strategic human resource management practices have no significant effect on the performance of manufacturing companies in Nigeria.

\section{Hypothesis Two:}

SHRM is not practiced by manufacturing companies in Nigeria.

\section{Hypothesis Three:}

There are no significant relationships among the different SHRM practices.

\section{Hypothesis Four:}

There is no significant relationship between the different SHRM practices and corporate performance of manufacturing companies in Nigeria.

\section{Research Methodology}

\subsection{Data Collection}

The population of this study is made up of all the companies operating in the Nigerian manufacturing sector. The study specifically uses a sampling frame consisting of 47 manufacturing companies listed on the Nigerian Stock Exchange (NSE) as at $30^{\text {th }}$ September, 2010. Questionnaires are sent to the heads of human resource departments of thirty manufacturing companies cutting across the following six industries: Health Care; Food and Beverages; Building Materials; Conglomerates; Printing and Publishing; and Paints and Chemicals. Stratified random 
sampling method is used in selecting the sampled companies from the study's population.

The unit of analysis in this study is the firm and multi-rater (multi respondents) response approach is adopted. Gerhart et al. (2000) contended that SHRM effects based on single respondent surveys were significantly undermined by the presence of measurement error in the SHRM measures. To minimize this error, three (3) questionnaires are sent to each company and it was addressed to the head of Human Resource Department who is required to be part of the three respondents. For each company, the composition of the respondents is: the head of HR Department, one senior HR staff and one other senior management staff outside the HR Department.

Since, the unit of analysis is the firm, the scores for each variable are aggregated and averaged over the three respondents for each company. For companies where the number of expected respondents is less than three, the average scores of the actual respondents are taken for each variable.

\subsection{Definition and Measurement of Variables}

\subsubsection{Dependent variables}

Corporate performance is measured by the following variables: growth rate of sales or revenue, financial strength (liquidity, reserve, borrowing capacity, e.t.c.), return on equity, return on assets and profitability. The variables are closely related conceptually to some of the hypothesized precursors of performance, such as HRM practices (Bae et al., 2003; Katou and Budhwar, 2007). These indicators are rated anonymously by the respondents on a 5-point likert scale $(1=$ Strongly Disagree; 5 = Strongly Agree $)$ and each rating is done in relation to the perceived performance of indicator of the best performing organization(s) in the industry to which the firm belongs. Respondents are asked the following questions: "compared to the performance of best performing organizations in your industry in Nigeria, how does your organization rate on each of the following in the last five years? " The ratings of all the indicators are aggregated and averaged across the respondents from the organization to derive an organization's score on the index of relative perceived corporate performance.

\subsubsection{Independent variables}

The independent variables (which collectively are a measure of SHRM practices) in this study are: strategic HRM alignment with business objectives and strategies, line management devolvement and line management training in HR practices, selection system, performance appraisal system, training and development system, compensation system, career planning system and employee participation. The items are derived from a comprehensive review of the literature on strategic HRM practices that are considered to relate to firm performance.

'Strategic HRM alignment' with business objectives and strategies is measured by ten (10) items, each rated on a 5-point scale ranging from 1 ' not at all' to 5 'to a great extent'. A sample item is 'HRM strategy is formulated based on your company's vision and mission'.

The 'Line management devolvement' variable is measured by asking respondents to indicate the involvement of line managers in the execution of five HR practices chosen on the basis of findings from previous research (e.g. Budhwar, 2000). Items are worded to emphasize the involvement of line managers in the execution of the following HR practices: 'recruits new people', 'select applicants', 'train employees', 'execute performance assessments' and design job roles'. An index is constructed by adding the five HR practices. Companies that indicate the involvement of line managers in one HR practice are scored a 1, two practices a 2, and so on, up to 5 . The range of the line management devolvement index is thus 0 to 5 .

The 'Line management training in HR practices' variable is measured by asking respondents to indicate the proportion of line managers trained in the firm to execute HR practices. The percentage of line managers training is scored on an ordinal scale from 1 'less than 10\%', to 10 'more than 90\%'. Firms that do not train its line managers in human resource practices are scored zero.

'Selection system' is measured by an instrument having 5 items each rated on a 5 -point scale. The respondents are asked to indicate on a scale of 1 'strongly disagree' to 5 'strongly agree' the importance their organizations attach to the usage of selection tools and tests. A sample item is 'the selection system followed in our company is highly scientific and rigorous'.

'Performance appraisal' is measured through an 8-item scale. The respondents are asked to indicate the extent to which performance is evaluated on the basis of quantifiable results and usage of performance appraisal data. In other words, they are to indicate on a scale of 1 'strongly disagree' to 5 'strongly agree' their agreement with some performance appraisal system in their organizations. A sample question is 'performance of the employees is measured on the basis of objective quantifiable results'.

'Compensation' system is measured through a scale having 5 items. The respondents are asked to indicate on a scale of 1 'strongly disagree to 5 'strongly agree' the extent to which compensation is linked to the performance and qualification of employees in their organizations. A sample question is 'in our company salary and other benefits are comparable to what is generally obtainable in the industry'.

'Training and development' variable is measured by an instrument having 7 items, each rated on a 5 -point scale. The respondents are asked to indicate on a scale of 1 'strongly disagree to 5 'strongly agree' the extent to which training and development needs in their organizations are identified and met. A sample question is 'employees in 
each job will normally go through training programs every year'.

'Career planning system' variable is measured by an instrument having 7 items, each rated on a 5 -point scale. The respondents are asked to indicate on a scale of 1 'strongly disagree to 5 'strongly agree' the clarity and usage of career planning system in their organizations. A sample question is 'our company provides clear career path information to employees'.

'Employee participation' is measured through a 3-item scale. The respondents indicated on a scale of 1 'strongly disagree to 5 'strongly agree' the extent to which superiors allow employees to participate in operations decisions as well as the opportunity given to suggest improvements in the way things are done. A sample question is 'employees in this company are provided opportunity to suggest improvements in the ways things are done'.

\subsubsection{Analytical Procedures}

Data collected is subjected to two main types of analysis. In order to gain perspectives into the socio-demographic characteristics of respondents, frequency distribution of responses is calculated while descriptive statistics is employed in determining the extent of strategic HRM practices in the companies under scrutiny. Other analytical procedures adopted include the correlation analysis to show the interrelationships among the identified strategic HRM practices and regression analysis to determine the predictor powers of the variables on organizational performance.

\section{Results and Discussions}

Of the 90 questionnaires distributed to 30 companies, a total of 63 completed and usable questionnaires from 21 companies representing a response rate of 70 percent are returned.

To address issues of possible common method variance, Cronbach Alpha reliability test is conducted for all the measures. Reliabilities are checked and they fall between 0.75 and 0.87 , which is satisfactory for study that is exploratory in nature (Nunnally, 1978). The overall Cronbach alpha of the ten scales used in this study is 0.81 . This indicates the reliability of the scales is reasonably high thus, depicting high internal consistency among the measurement items.

\subsection{Demographic Characteristics of the Respondents}

Table 1 shows the demographic characteristics of the respondents. Majority of the respondents (91 percent) possess educational qualification higher than diploma or its equivalent and about 75 percent of the respondents are in the rank of senior manager and above. This is an indication that the respondents are highly rated employees who should know more about the human resource management practices of their respective companies.

About 79 percent of the respondents have put in at least 5 years of service and majority of the them ( 84 percent) are married. About 94 percent of the respondents are at least than 30 years old.

In general, the study gives a favourable picture concerning the level of education of the respondents. A substantial proportion of the respondents have at least a first degree. This is an indication that the respondents are composed of highly educated people.

Majority of the respondents have put in at least five years of service. This is also an indication that the respondents have actually spent enough time in the service to know how strategic the management of the companies is.

\subsection{Extent of Strategic Human Resource Management Practices}

Table 2 presents the descriptive statistics of the variables. The mean score of the strategic HRM alignment with the overall organizational goals and objective is 38.37 out of a possible maximum score of 50, suggesting a high (76.74\%) extent of strategic HRM alignment with the overall business objectives.

To assess the tendency of organizations to devolve human resource practices to line officers, two criteria are used, namely, the involvement and training of non-personnel officers (e.g. Accountants) in human resource practices. Based on a possible maximum score of 5 in five HR practices, the results reveal that line mangers executed a mean of $3.31(66.2 \%)$ human resource practices indicating a moderate involvement of line managers in the execution of human resource management practices.. In terms of the second criterion for devolvement (i.e. training provided to line mangers to execute HR practices), the finding shows a low level of training given to non-personnel officers as only $25.3 \%$ of line managers are trained to execute HR practices.

Employee selection system records a mean score of 16.24 (64.96\%) out of possible maximum score of 25 . The result indicates a moderate fit between the prospective employee's abilities and qualifications and the organization's requirements. Training and development on the other hand, has a mean score of $22.69(64.83 \%)$ out of a possible maximum score of 35 depicting a moderate level of employees' participation in training and development programs.

The mean score of performance appraisal system is $25.05(62.62 \%)$ out of a possible maximum score of 40 . Results reveal that personnel appraisal system currently being practiced is impressive enough to allow the companies to be able to monitor the development of desired employee attitudes and behavious through the use of the appraisal mechanism. Compensation system has a mean score of $17.05(68.2 \%)$ out of a possible maximum score of 25 depicting an impressive fit between perceived compensation system in the Nigerian manufacturing 
sector and the overall industry policy on compensation of workers.

The mean scores of career planning system and employee participation are found to be $24.03(68.66 \%)$ and 11.32 (75.47\%) out of a possible maximum scores of 35 and 15 respectively. The result indicates a high level of effective career planning system and employee participation within the Nigerian manufacturing sector.

\subsection{Relationship between Strategic HRM Practices and Organizational Performance}

As shown in Table 3, the zero-order correlation between line management devolvement and organizational performance is $r=0.35$. While selection system has significant positive relationship with organizational performance with a correlation $(\mathrm{r})=0.57$.

Training and development and performance appraisal system have a significant positive relationship with organizational effectiveness with a correlation (r) of 0.76 and 0.73 respectively. Similarly, compensation system and career planning system also have a significant positive relationship with organizational effectiveness with a correlation (r) of 0.71 and 0.85 respectively. Employee participation is also found to be positively correlated with organizational effectiveness with a correlation ( $\mathrm{r}$ ) of 0.38 . The above correlations are all significant at the 0.01 significance level.

The results also suggest a weak but positive relationship between strategic HRM alignment with organizational performance with a correlation (r) of 0.23 . Similarly, line management training in HR practices also shows a weak but, positive relationship with organizational effectiveness with a correlation (r) of 0.19 . The results are however, not significant at both 0.05 and 0.01 level of significance. These results provide preliminary support for hypothesis four.

\subsection{Relationship among the Individual Strategic HRM Practices}

As presented in Table 3 above, results suggest a significant positive correlation between strategic HRM alignment with the following practices: line management devolvement, selection system, compensation system, career planning system and employee participation with correlations ( $\mathrm{r}$ ) of $0.46,0.17,011,0.28$, and 0.31 respectively. It however shows a significant negative relationship with training and development and performance appraisal system with a correlation (r) of -0.15 and -0.09 respectively.

Results also show that line management devolvement has a significant positive relationship with the following practices: line management training, selection system, training and development system, and performance appraisal system with correlations (r) of $0.43,0.45,0.51$, and 0.37 respectively.

Training of line managers in HR practices has a significant positive relationship with selection system, training and development and performance appraisal system with correlations (r) of 0.36, 0.35 and 0.19 respectively.

Results indicate that selection system has a significant strong positive relationship with the following practices: training and development, performance appraisal system, compensation system, career planning system and employee participation with correlations ( $\mathrm{r}$ ) of $0.89,0.83,0.77$, and 0.81 respectively. It however has a significant moderate positive relationship with employee participation with a correlation of 0.47 .

Training and development also has a significant strong positive relationship with performance appraisal system, compensation system and career planning system with correlations (r) of $0.88,0.79$ and 0.90 respectively. Results also indicate that performance appraisal system has a significant strong positive relationship with compensation system and career planning system with correlations (r) of 0.84 and 0.92 respectively.

Results also show that compensation system has a significant strong relationship with career planning system with a correlation of 0.87 . Career planning system is also found to have a significant weak positive relationship with employee participation with a correlation (r) of 0.31 .

\subsection{Effect of Strategic HRM Practices on Organizational Performance}

As shown in Table 4, there is a strong positive relationship between strategic HRM practices and organizational effectiveness with a multiple correlation (R) of 0.93 . The adjusted $\mathrm{R}^{2}$ of 0.83 implies that $83 \%$ of the variations in organizational performance are adequately explained by strategic HRM practices used in this study.

The results also show that strategic HRM alignment with overall corporate objectives and line management devolvement has a positive effect on organizational effectiveness with coefficients of 0.20 and 0.091 respectively. Selection system and training and development were also found to have a positive effect on organizational performance with coefficients of 0.773 and 0.851 respectively.

Performance appraisal system, compensation system, career planning system and employee participation are also found to have a positive effect on organizational effectiveness with coefficients of 1.032, 0.953, 1.074 and 0.09 respectively.

At 5 percent level of significance, the F-statistics shows that the model is useful in determining if any significant relationship exists between strategic HRM practices and organizational effectiveness.

\section{Discussions}

The results of this study indicate that HRM is highly integrated into the companies' business operations. 
In contrast, the empirical evidence regarding devolvement reflects a mixed story. While line managers are involved in the execution of HR practices, on average the level of training given to line mangers to perform these practices is low (25 percent) which indicates that the transfer of HRM knowledge to line managers is somewhat limited. Insufficient training offered to line managers would greatly undermine the capacity of line managers to perform HR activities effectively.

The results also indicate that all the strategic HRM practices tested in this study: strategic HRM alignment, line management devolvement, line management training, training and development, compensation system, career planning system and employee participation are all positively related to perceptual measures of organizational performance in the Nigerian manufacturing sector.

Overall the model is supported by data and the results suggest that line management devolvement, selection system, regular training and development of personnel, equity based compensation system, performance appraisal system, effective career planning system and a robust employee participation in the organizations' decisions and actions are the key strategic HR practices that influence organizational performance in the Nigerian manufacturing sector. It therefore, implies that companies operating in the Nigerian manufacturing sector should pay more attention to these practices with a view to improving their implementation across the industry.

\section{Conclusion}

The results obtained from this study indicate that strategic HRM is moderately practiced by companies operating in the Nigerian manufacturing sector and that performance symbolized by growth rate of revenue, financial strength, return on equity, return on assets and profitability is reasonably enhanced by eight out of the nine strategic HRM practices tested. The study, to this extent, has provided evidence for the value-added by strategic HRM through the integration of HR function within the organization's key strategies and operations. Be that as it may, questions need to be asked on the results of moderate levels of involvement in Strategic HRM practices as against high levels reported elsewhere. Can this be simply passed off as problems of new concept, data specification, procedures or even interpretation? Can this result even be attributed to factors other than strategic HRM practices? These are questions that can be resolved under different settings. However, managers everywhere face the same challenges of tackling complex problems with limited resources, determining priorities, motivating staff, initiating change and demonstrating measurable results. Strategic HRM in concept and practice is about managers standing in the front lines to tackle these challenges to achieve organizational objectives. We should be reminded that people may know everything about line management devolvement but not practice it; people may know the virtues of employee participation but not apply it. It is therefore, down to commitment as the missing link.

To achieve employee commitment, the weather of the work place has to be supportive to lead to and sustain staff motivation and high performance (Litwin and Stringer, 1968; Stringer, 2002). No doubt, Strategic HRM practices identified in this study should play this role creditably well and to act as catalyst, organizations should consider the benefits of integrating their HR function with its overall strategies and operations.

\section{References}

Bae, J., Chen, S., Wan, T.W.D., Lawler, J. J., and Walumba, F. O. (2003). Human Resources Strategy and Firm Performance in Pacific Rim Counties. International Journal of Human Resource Management, 14(8): 1308-1332. doi:10.1080/0958519032000145774, http://dx.doi.org/10.1080/0958519032000145774

Barak, M., Maymon T., and Harel, G. (1999). Team Work in Modern Organizations: Implications for Technological Education. International Journal of Technology and Design Education, 9: 85-101. doi:10.1023/A:1008849803984, http://dx.doi.org/10.1023/A:1008849803984

Becker, B., and Gerhart, B. (1996). The Impact of Human Resource Management on Organizational Performance: Progress and Prospects. Academy of Management Journal, 39: 779-801. doi:10.2307/256712, http://dx.doi.org/10.2307/256712

Bowen, D. E., and Ostroff, C. (2004). Understanding HRM-Firm Performance Linkages: The Role of the 'Strength' of the HRM System. Academy of Management Review, 29(2): 203-21.

Budhwar, P. (2000). Strategic Integration and Devolvement of Human Resource Management in the UK Manufacturing Sector. British Journal of Management, 11(4): 285-302. doi:10.1111/1467-8551.00174, http://dx.doi.org/10.1111/1467-8551.00174

Budhwar, P., and Khatri, N. (2001). HRM in Context: Applicability of HRM Models in India. International Journal of Cross Cultural Management, 1(3): 333-56. doi:10.1177/147059580113005, http://dx.doi.org/10.1177/147059580113005

Buyens, D., and De Vos, A. (2001). Perception of the Value of the HR Function. Human Resource Management Journal, 11(3): $70-89 . \quad$ doi:10.1111/j.1748-8583.2001.tb00046.x, http://dx.doi.org/10.1111/j.1748-8583.2001.tb00046.x

Cheddie, M. (2001). How to Become a Strategic Partner. HR Focus, 78(8): 1-14. 
Cunningham, J. B., and Deborah, Y. A. (1995). Skills for Managing Human Resources in a Complex Environment: the Perceptions of Human Resource Managers in Singapore. International Journal of Human Resource Management 6(1): 79-101. doi:10.1080/09585199500000004, http://dx.doi.org/10.1080/09585199500000004

David, W., Chin, H. O., and Victor, K. (2002). Strategic Human Resource Management and Organizational Performance in Singapore. Compensation and Benefits Review, 34: 33-42. doi:10.1177/0886368702034004006, http://dx.doi.org/10.1177/0886368702034004006

Dimba B., and K'Obonyo P. (2009). The Effect of Strategic Human Resource Management Practices on Performance of Manufacturing Multinational Companies in Kenya: Moderating Role of Employee Cultural Orientations and Mediating Role of Employee Motivation. Proceedings of the International Conference on Human Capital Management in University of Nairobi, July $22-24$.

Ferris, G. R., Russ, G. S., Albanese, R., \& Martocchio, J. J. (1990). Personnel/Human Resources Management, Unionization, and Strategy Determinants of Organizational Performance. Human Resource Planning, 13, 215-227.

Gerhart, B., Wright, P.M., McMahan, G., and Snell, S.A. (2000). Measurement Error in Research on Human Resources and Firm Performance: How Much Error is There and How Does it Influence Effect Size Estimates? Personnel Psychology, 53, 4, 803-834. doi:10.1111/j.1744-6570.2000.tb02418.x, http://dx.doi.org/10.1111/j.1744-6570.2000.tb02418.x

Green, W. K., Wu, C., Whitten, D., and Medlin, B. (2006). The Impact of Strategic Human Resource Management on Firm Performance and HR professionals' Work Attitude and Work Performance. International Journal of human resource Management, 8(3): 263-276.

Hall, L., and Torrington, D. (1998). Letting Go or Holding On: The Devolution of Operational Personnel Activities. Human Resource Management Journal, 8: 41-55. doi:10.1111/j.1748-8583.1998.tb00158.x, http://dx.doi.org/10.1111/j.1748-8583.1998.tb00158.x

Hope-Hailey, V., Gratton, L, McGovern, P, Stiles, P., and Truss, C. (1997). A chameleon function? HRM in the '90s. Human Resource Management Journal, 7(3): 5-19. doi:10.1111/j.1748-8583.1997.tb00421.x, http://dx.doi.org/10.1111/j.1748-8583.1997.tb00421.x

Huang T. (1998). The Strategic Level of Human Resource Management and Organizational Performance: An Empirical Investigation. Asia Pacific Journal of Human Resources, 36(2): 59-72. doi:10.1177/103841119803600206, http://dx.doi.org/10.1177/103841119803600206

Kai, K., A., Brian, K. P., and Cherrie, J. Z. (2007). The Effect of SHRM Practices on Perceived firm Financial performance: Some Initial evidence from Australia. Asia Pacific Journal of Human Resources, 46; 168-179.

Katou, A. and Budhwar, P. (2007). The Effect of Human Resource Management Policies on Organizational Performance in Greek Manufacturing Firms. Thunderbird International Business Review, 4991): 1-35.

Khatri, N. (1999). Emerging Issues in Strategic HRM in Singapore. International Journal of Manpower, 20(8): 51-2. doi:10.1108/01437729910302714, http://dx.doi.org/10.1108/01437729910302714

Litwin G. H., and Stringer R. A. (1968). Motivation and Organizational Climate. Cambridge: Harvard University Press.

Martell, K., and Carroll, S. J. (1995). How Strategic is HRM? Human Resource Management, 34 (2): 253-67. doi:10.1002/hrm.3930340203, http://dx.doi.org/10.1002/hrm.3930340203

Milkovich, T. G., and Boudreau, W. J. (1998). Human Resource Management, $8^{\text {th }}$ edt. Boston: Irwin.

Nunally, J. C. (1978). Psychometric Theory. $2^{\text {nd }}$ Ed. New York: McGraw-Hill.

Okpara J. O., and Pamela W. (2008). HRM Practices in a Transition Economy: Challenges and Prospects. Management Research News, Vol. 31 (1): 57 - $76 . \quad$ doi:10.1108/01409170810845958, http://dx.doi.org/10.1108/01409170810845958

Pfeffer, J. (1994). Competitive Advantage through People. Boston: Harvard Business School Press.

Schuler, R., and Jackson, S. (1999). Linking Competitive Strategies with Human Resource Management Practices. In Strategic human resource management, eds R. Schuler and S. Jackson, 159-76. Oxford: Blackwell Publishers Ltd.

Schuler, R.S. (1992). Linking the People with the Strategic Needs of the Business. Organizational Dynamics, Summer: 18-32. doi:10.1016/0090-2616(92)90083-Y, http://dx.doi.org/10.1016/0090-2616(92)90083-Y

Singh, K. (2004). Impact of HR Practices on Perceived Firm Performance in Indian. Asia Pacific Journal of Human Resources. 42: $301 \quad-\quad 317 . \quad$ doi:10.1177/1038411104048170, http://dx.doi.org/10.1177/1038411104048170

Som A. (2008). Innovative Human Resource management and Corporate performance in the Context of Economic Liberalization in India. Thunderbird International Business Review, 49(2): 1-33. 
Stringer R. A. (2002). Leadership and Organizational Climate: The Cloud Effect. Upper Saddle River, NJ: Prentice Hall.

Teo, S. (2002). Effectiveness of a Corporate HR Department in an Australian Public Sector Entity during Commercialization and Corporatization. International Journal of Human Resource Management, 13(1): 89-105. doi:10.1080/09585190110092820, http://dx.doi.org/10.1080/09585190110092820

Terpstra, D. E., and Rozell, E. J. (1993). The Relationship of Staffing Practices to Organizational level Measures of Performance. Personnel Psychology, 46: 27-48. doi:10.1111/j.1744-6570.1993.tb00866.x, http://dx.doi.org/10.1111/j.1744-6570.1993.tb00866.x

Tessema, M. T., and Soeters, J. L. (2006). Challenges and Prospects of HRM in Developing Countries: Testing the HRP-Performance Link in Eritrea Civil Service. International Journal of Human Resource Management, 17(1): 86-105. doi:10.1080/09585190500366532, http://dx.doi.org/10.1080/09585190500366532

Tichy, N. M., Fombrun, C. J., and Devanna, M. A. (1982). Strategic Human Resource Management. Sloan Management Review, 23: 47-61

Verma, A. (1995). Employee Involvement in the Workplace. In Research in Personnel and Human Resource Management, (Eds). M. Gunderson and a. Ponak. New Haven, CT: JAI press.

Wright, P. M., and McMahan, G. C. (1999). Theoretical Perspectives for SHRM. In Strategic Human Resource Management, (Eds.) R. Schuler and S. Jackson, 49-72. Oxford: Blackwell Publishers Ltd.

Wright, P.M., Gardner, T.M., \& Moynihan, L. M. (2003). The Impact of HR Practices on the Performance of Business Units. Human Resource Management Journal, 13, 21-36. doi:10.1111/j.1748-8583.2003.tb00096.x, http://dx.doi.org/10.1111/j.1748-8583.2003.tb00096.x

Table 1. Demographic Characteristics of the Respondents $(\mathrm{N}=63)$

\begin{tabular}{|l|c|c|}
\hline Characteristics & Frequency & Percentage \\
\hline Level of Education & & \\
Diploma or its equivalent & 6 & 9.5 \\
B.Sc or its equivalent & 24 & 52.4 \\
Master Degree & $\mathbf{6 3}$ & 38.1 \\
Total & & $\mathbf{1 0 0}$ \\
\hline Job Title & 16 & 25 \\
Assistant managers & 28 & 45 \\
Senior Managers & 19 & 30 \\
General Managers \& Above & $\mathbf{1 0 0}$ & $\mathbf{1 0 0}$ \\
Total & & \\
\hline Years of Service & 13 & 21 \\
1 - 4 years & 37 & 59 \\
5-10 years & 13 & 20 \\
10 years \& above & $\mathbf{6 3}$ & $\mathbf{1 0 0}$ \\
Total & & 11 \\
\hline Marital Status & 7 & 84 \\
Single & 53 & 5 \\
Married & 3 & $\mathbf{1 0 0}$ \\
Divorced/separated & $\mathbf{6 3}$ & 6 \\
Total & & 45 \\
\hline Age of Respondents & 4 & 49 \\
21 - 30 years & 28 & $\mathbf{1 0 0}$ \\
31 - 40 years & 31 & \\
41 years \& above & $\mathbf{6 3}$ & \\
Total & & \\
\hline
\end{tabular}

Source: Field Survey, 2010 
Table 2. Descriptive Statistics of the Measurement Variables

\begin{tabular}{|l|c|c|}
\hline \multicolumn{1}{|c|}{ Measurement Variables } & Mean & Standard Deviation \\
\hline Strategic HRM alignment & 38.37 & 5.321 \\
\hline Line Management Devolvement & 3.31 & 0.814 \\
\hline Line Management Training & 1.25 & 0.613 \\
\hline Selection System & 16.24 & 1.645 \\
\hline Training and Development & 22.69 & 2.992 \\
\hline Performance appraisal system & 25.05 & 2.453 \\
\hline Compensation System & 19.46 & 1.456 \\
\hline Career Planning System & 27.53 & 2.614 \\
\hline Employee Participation & 11.32 & 1.325 \\
\hline Organizational Performance & 31.04 & 3.211 \\
\hline
\end{tabular}

Source: Author's Computations using SPSS, 2010

Table 3. Correlation Matrix of the Measurement Variables

\begin{tabular}{|l|llllllllll|}
\hline Variables & 1 & 2 & 3 & 4 & 5 & 6 & 7 & 8 & 9 & 10 \\
\hline 1. Strategic HRM Alignment & 1.00 & $\mathbf{0 . 4 6}$ & .23 & $\mathbf{. 1 7}$ & $\mathbf{- . 1 5}$ & $\mathbf{. . 0 9}$ & $\mathbf{. 1 1}$ & $\mathbf{. 2 8}$ & $\mathbf{. 3 1}$ & .23 \\
2. Line Mgt. Devolvement & & 1.00 & $\mathbf{. 4 3}$ & $\mathbf{. 4 5}$ & $\mathbf{. 5 1}$ & $\mathbf{. 3 7}$ & -.01 & .23 & .08 & $\mathbf{. 3 5}$ \\
3. Line Mgt Training in HR & & & 1.00 & $\mathbf{. 3 6}$ & $\mathbf{. 3 5}$ & $\mathbf{. 1 9}$ & $\mathbf{. 1 4}$ & .01 & .09 & $\mathbf{. 1 9}$ \\
4. Selection System & & & & 1.00 & $\mathbf{. 8 9}$ & $\mathbf{. 8 3}$ & $\mathbf{. 7 7}$ & $\mathbf{. 8 1}$ & $\mathbf{. 4 7}$ & $\mathbf{. 5 7}$ \\
5. Training \& Development & & & & & 1.00 & $\mathbf{. 8 8}$ & $\mathbf{. 7 9}$ & $\mathbf{. 9 0}$ & .17 & $\mathbf{. 7 6}$ \\
6. Performance Appraisal & & & & & & 1.00 & $\mathbf{. 8 4}$ & $\mathbf{. 9 2}$ & .12 & $\mathbf{. 7 3}$ \\
7. Compensation System & & & & & & & 1.00 & $\mathbf{. 8 7}$ & .21 & $\mathbf{. 7 1}$ \\
8. Career Planning System & & & & & & & & 1.00 & $\mathbf{. 3 1}$ & $\mathbf{. 8 5}$ \\
9. Employee Participation & & & & & & & & & 1.00 & $\mathbf{. 3 8}$ \\
10. Organizational Performance & & & & & & & & & & 1.00 \\
\hline
\end{tabular}

Note: Bold correlations are significant at either 0.05 or 0.01 level of significance (two-tailed).

Source: Author's Computations using SPSS, 2010

Table 4. Regression Results on Perceived Organizational Performance

\begin{tabular}{|l|c|c|}
\hline Independent Variables & Standardized Coefficients & t-values \\
\hline Strategic HRM Alignment & 0.196 & $5.324^{*}$ \\
Line Mgt. Devolvement & 0.091 & 1.053 \\
Line Mgt Training in HR & 0.573 & 0.856 \\
Selection System & 0.773 & $6.235^{*}$ \\
Training \& Development & 0.851 & $2.378^{*}$ \\
Performance Appraisal & 1.032 & $4.715^{*}$ \\
Compensation System & 0.953 & $1.371^{*}$ \\
Career Planning System & 1.074 & $9.732^{*}$ \\
Employee Participation & 0.09 & $2.311^{*}$ \\
R & 0.93 & \\
$\mathrm{R}^{2}$ & 0.85 & \\
Adjusted $\mathrm{R}^{2}$ & 0.83 & \\
$\mathrm{~F}$ & $149.51^{*}$ & \\
$\mathrm{~N}$ & 21 & \\
\hline
\end{tabular}

Dependent Variable $=$ Organizational Performance

*Significant at 0.05 level of significance. 